\title{
Cell therapy for severe burn wound healing
}

Zhe $\mathrm{Li}^{1,2,3^{*}}$ and Peter Maitz ${ }^{1,2,3}$

\begin{abstract}
Cell therapy has emerged as an important component of life-saving procedures in treating burns. Over past decades, advances in stem cells and regenerative medicine have offered exciting opportunities of developing cell-based alternatives and demonstrated the potential and feasibility of various stem cells for burn wound healing. However, there are still scientific and technical issues that should be resolved to facilitate the full potential of the cellular devices. More evidence from large, randomly controlled trials is also needed to understand the clinical impact of cell therapy in burns. This article aims to provide an up-to-date review of the research development and clinical applications of cell therapies in burn wound healing and skin regeneration.
\end{abstract}

Keywords: Skin, Burn injuries, Stem cells, Cell therapy, Wound healing, Skin regeneration

\section{Background}

Burns remain one of the most traumatic injuries causing significant health, social and economic consequences [1]. Globally, severe burns lead to about 180,000 deaths annually and millions of patients suffering from non-fatal burns experiencing substantial and life-long physical and psychological morbidities.

Severe burn wound is characterised by the destruction of skin structures, functions and more importantly the loss of the progenitor cell populations that are essential for regenerating and restoring the structures and functions [2]. Until now, autologous skin grafting remains a standard practice in treating severe burns. However, its effectiveness is often challenged in treating severe burn patients with limited donor sites for skin graft harvesting. Consequently, the patients could experience a significant delay in wound closure, detrimental infection, scarring or even death.

To overcome the autograft shortage, a variety of alternatives for autologous skin grafts including allogeneic skin, xenografts and synthetic skin substitutes have been widely adopted in burn wound care $[3,4]$. While those alternative devices provide temporary wound coverage and deliver various bio-factors to facilitate the angiogenesis and granulation of wound bed for further surgery, they could never replace the skin autograft delivering the essential

\footnotetext{
* Correspondence: zhe.li1@sydney.edu.au

${ }^{1}$ Burns Unit, Concord Hospital, Concord, New South Wales 2139, Australia

${ }^{2}$ Skin Laboratory, NSW Statewide Burns Service, Concord, New South Wales,

Australia

Full list of author information is available at the end of the article
}

autologous progenitor cells that could replicate to regenerate skin tissues for permanent wound closure. In past decades, cell-based therapies have emerged as popular choices in conjunction with standard skin grafting techniques for burn wound healing and regeneration of skin structure and functions. This article aims to provide an up-to-date review of the research development and clinical applications of cell therapies in severe burn wound healing.

\section{Review \\ Development of cell therapy for burn wound healing}

Cell therapy which also called cellular therapy or cytotherapy involves delivering an autologous or allogenic cellular component into a patient to repair or regenerate the damaged tissue due to injuries or diseases, to rectify the diseased conditions associated with the damages or deficiency of the unique cell population and to restore the physiological functions.

Skin as the multi-functional and protective barrier in human contains essential stem cell population and various cellular types that are critical for renewing and maintaining its structural integrity and functions. Research on skin cell transplantation for wound healing was first reported by Billingham and Reynolds in 1952 [5]. In a guinea pig model, they harvested both epidermal sheets and epidermal cell suspension by trypsin digestion and then transplanted them to surgically created wounds to evaluate their possible application in plastic surgery, experimental pathology, wound healing and 
contracture release. However, the era of cultured cell therapy for burn injuries was only opened up after Rheinwald and Green revolutionised the cell culture technique in 1975 allowing the isolation and serial cultivation of strains of human keratinocytes from a skin biopsy [6]. For the first time, epithelial sheets could be produced using cultured keratinocyte clones [7] in laboratory and cultured epithelia autografts (CEAs) were successfully transplanted in severe burns for wound healing [8]. The encouraging report further sparked worldwide research activities on cell therapy in burn research. Progresses as described in the following sections have been achieved over past decades to understand various cell types and their potential roles in burn wound healing.

\section{Different cell types with therapeutic potentials}

Wound healing and restoration of skin structures and functions depend on many factors including the availability of essential progenitor cells, dermal extracellular matrix (ECM), and bio-factors and cytokines for angiogenesis and regulation of cell-matrix and cell-cell interactions. The following cell types have demonstrated potentials as therapeutic devices in skin wound healing and tissue regeneration. Many autologous and allogeneic cell products were developed using cells of skin and non-skin origins for therapeutic application in burn wound management.

\section{Keratinocyte stem cells}

The epidermis is mainly comprised of keratinocytes which are renewed and sustained by keratinocyte stem cell (KSC) populations anchored at the membrane in the epidermal-dermal junction, the hair follicle bulge and the sebaceous gland $[9,10]$. KSCs, expressing K5, K14 and p63, are well known for regulating epithelial stratification, hair folliculogenesis and wound repair [10-12].

Based on molecular biomarkers, regenerative capability and the status of cellular differentiation, keratinocytes in human skin could be classified as KSCs, transient-amplifying keratinocytes and differentiated keratinocytes [13]. The KSCs, making about $4 \%$ to $8 \%$ of total keratinocyte population in skin [14], are localised at dermal-epidermal junction, hair follicles and the surrounding zones of skin appendages. They replicate themselves by asymmetric division to maintain a stable population of undifferentiated stem cells at the basal region and are essential for epidermal regeneration or repair due to skin injuries. Beta4 integrin is required for hemidesmosome formation, cell adhesion and cell survival [15]. During normal epidermal homeostasis or repair, the KSCs go through asymmetric division, exiting their niche, transforming into transient-amplifying keratinocytes and migrating towards skin surface to form multiple keratinocytes layers [11]. They gradually lose the capacity in population doublings through differentiation [10-15]. KSC populations with more active, proliferative and regenerative capacities are observed in young people comparing to aged peoples [16].

The keratinocytes can be easily isolated and expanded in numbers under in vitro cell culture conditions. Keratinocytes produce various bio-factors and cytokines including interleukin (IL)-1, IL-6, IL-7, IL-8, IL-10, IL-12, IL-15, IL-18, and IL-20 and tumour necrosis factor alpha (TNF- $\alpha$ ) [17], which are important for regulating skin regeneration and wound healing. All these properties make them the most important and widely used cells for therapeutic application in burn wound care.

A population of circulating keratinocyte progenitor cells (KPCs) was identified with p63 in peripheral blood, which differentiated into keratinocytes with expression of the cytokeratins, involucrin and filaggrin [18].

\section{Dermal fibroblasts}

Dermal fibroblast cells play an important role in normal skin and skin wound healing post-burn. They produce the key ECM proteins in the dermis including laminins, fibronectins, collagens, elastic fibres, non-collagen molecules and bio-factors to regulate cell function, migration and the cell-matrix and cell-cell interactions in normal skin homeostasis and wound healing [19-21]. Dermal fibroblast cells produce many growth factors and cytokines including vascular endothelial growth factor (VEGF), basic fibroblast growth factor (bFGF), hepatocyte growth factor (HGF), platelet-derived growth factor (PDGF)-AA, transforming growth factor-beta1 (TGF- $\beta 1$ ) , keratinocyte growth factor (KGF), IL-6 and IL-8 and tissue inhibitors of metalloproteinases [19-21]. Cryopreserved cultured dermal substitute maintained sufficient fibroblast cell viability and the ability to proliferate and release a significant amount of VEGF [22]. Epidermalderived pro-inflammatory cytokines IL- $1 \alpha$ and TNF- $\alpha$ mediate synergistically the secretion of wound-healing mediators (with the exception of sST2) from fibroblasts in dermal substitutes. Studies demonstrated a synergistic enhancement of the expression of bio-factors including IL$1 \alpha$, IL-6, bFGF, CCL2, CXCL1, CXCL8, and sST2 if KSCs and dermal fibroblast cells were co-cultured in a dermal regenerative scaffold [21, 23, 24].

Skin-derived precursor (SKP) cells have also been isolated from dermal papillae and can be differentiated into adipocytes, smooth myocytes and neurons in vitro [25, 26]. Fibroblasts from adult mouse and human can be induced 
into pluripotent stem cells with potentials for regeneration of various tissues $[27,28]$.

\section{Mesenchymal stem cells}

Mesenchymal stem cells (MSCs), a unique population of multipotent cells with self-renewal and regenerative capacity can be derived from autologous or allogenic tissues including bone marrow, adipose tissue, nerve tissue and umbilical cord and cord blood, and dermis. MSCs express surface CD markers including CD44+, CD73+, CD90+ and CD105+ and are distinguished from haematopoietic cells by a lack of CD34, CD14, CD45, CD11b/CD79 and CD19/ HLA-DR [29-32].

MSCs produce and release bio-factors [33-37] such as VEGF, stromal cell-derived factor-1, epidermal growth factor, KGF, insulin-like growth factor and matrix metalloproteinase-9 promoting angiogenesis; recruit endogenous progenitor cells; and direct cell differentiation, proliferation and ECM formation during wound repair. MSCs also secrete cytokines including interferon- $\lambda$, TNF- $\alpha$, IL- $1 \alpha$ and IL- $1 \beta$, and nitric oxide to modulate host immune response in wound healing [33, 36, 37].

Studies demonstrated that both autologous and allogenic MSCs, administered both systemically or and locally, exhibit therapeutic potentials promoting cutaneous wound healing and tissue regeneration via the paracrine bio-factors and cytokines and the multipotency in tissue regeneration [31, 32, 38-40]. Under specific niche conditions and molecular stimulations, MSCs could be induced to differentiate into multiple tissue-specific cell lineages including osteoblasts, adipocytes, chondrocytes, tenocytes, myocytes, endothelial cells, vascular smooth muscle cells, keratinocytes and sweat gland-like structures [35, 37, 41]. MSCs could produce anti-fibrotic factors and modulate development of hypertrophic scarring [42]. Adiposederived stem cells (ADSCs) and ADSC-conditioned medium appear highly effective in promoting hair growth [43, 44], and development of functional sweat gland-like structures was observed from transplanting differentiated bone marrow mesenchymal stem cells (BM-MSCs) [45]. MSCs promote angiogenesis and vascular stability that are critical for delivering the essential nutrient supply for tissue regeneration and wound healing [46].

\section{Induced pluripotent stem cells}

Human embryonic stem cells (hESCs), derived from human embryos are well known for their pluripotent capacities in tissue regeneration. Research demonstrated that hESCs could be induced to efficiently differentiate into functional basal keratinocytes that regenerate a pluristratified epidermis [47-51]. Immortalised keratinocyte lines [52] and fibroblasts [53] were also derived from hESCs. The hESCs-derived fibroblasts were observed to direct development and repair of three dimensional (3D) human skin equivalents [53].

Although hESCs could be developed to provide temporary skin substitutes for burn patients awaiting autologous grafts, the potential applications are however complicated due to the ethical issues in relation to using human embryos.

The Nobel Prize winning discovery of induced pluripotent stem cells (iPSCs) by Yamananka and his team brought an alternative source of stem cells with pluripotent potentials for therapeutic applications [27, 28]. While avoiding the ethical concerns in using hESCs, they induced adult mouse or human dermal fibroblasts into pluripotent stem cells by transforming them with Sox2, Oct4, Klf4 and c-Myc transcription factors using a retroviral system. The generated iPSCs are, although not identical, extremely similar to embryonic stem cells being capable of generating all cell lineages of different tissues including skin $[49,54]$. iPSC-derived cells could secrete proteins including VEGF, FGF-2, TGF- $\beta$, S100A4, GRO, GM-CSF, MCP-1, IL-6 and IL-8 that promote increased proliferation, contraction and migration [55]. iPSCs as patient specific or allogenic devices demonstrated potential values for clinical applications, research and drug discoveries in laboratory research. Their safety and efficacy are still to be assessed mainly due to the use of retroviral vectors, associated risk, genetic instability and potential immunogenicity [56]. To avoid the risks of mutagenesis and oncogenic transformation associated with retroviral vector, iPSCs are also generated with non-integrative reprogramming strategies using plasmid vectors, episomal plasmid vectors, modified/microRNA or even direct delivery of reprogramming protein factors [57-59]. The non-integrative reprogramming strategies were considered safer for therapeutic purpose. However, the efficiency of iPSC induction by original plasmid vector was low although it could be enhanced by essential factor for episomal amplification of the vector [58].

\section{Clinical research and applications of cell-based therapies in burn wound care \\ Cultured epithelial autografts}

The key technique that Rheinwald and Green established in the 1970s for serial culture of keratinocytes opened the era of research and therapeutic uses of cultured autologous keratinocytes in burn wound healing. Under laboratory conditions, KSCs could be isolated from a small skin biopsy and cultivated in the presence of growth-arrested 3T3 mouse fibroblasts as feeder cells to form epidermal sheets that could be transplanted back 
to the same patient for treatment. The innovative technology quickly gained global attention and emerged as a popular way to generate alternative autografts to facilitate permanent wound closure when treating severe burns. Since 1981, both cultured living keratinocytes and epithelial autograft sheets (CEAs), either produced in house or by commercial companies, have been used as clinical devices in treating large burns [8, 60-67].

Cultured keratinocytes were used for treating burns in various ways. Commonly, the cells from a skin biopsy are cultivated, screened and passaged in a cell culture system to expand the numbers of KPCs. In the presence of feeder fibroblast cells, the keratinocytes could proliferate and differentiate to form an epidermis-like tissue in cell culture. The process of CEA cultivation usually requires about 3 weeks depending on many factors including patient age, health condition and severity of burn injuries. The colony-forming efficiency of keratinocytes from freshly trypsinised skin was reported very low, between $0.15 \%$ and $3.8 \%$ in the primary cell culture [68-70] but was increased to $26 \%$ to $90 \%$ at passage 2 to 3 cultures and to over 16\% in CEA sheets [70], being significantly higher than that $(4-8 \%)$ in normal skin [14]. Cultured epidermis can be harvested as a sheet graft for clinical application.

Cultured human sole-derived keratinocyte grafts reexpress site-specific differentiation after transplantation [71]. The formation of hair follicles and development of normal epidermal microarchitecture were observed when epidermal cells were transplanted together with cells of dermal origin [72].

Very often, CEAs were used in combination with widely meshed skin grafts for wound closure. CEAs could be transplanted directly to the wound area $[8,73]$ with undifferentiated progenitor cells attached to the regenerated or freshly debrided wound bed [74]. CEAs were of significant value in severe burn management, providing wound coverage, facilitating wound epithelisation and permanent closure, and improving survival rates among patients with massive burn wounds [7578]. CEA demonstrated a very high beneficial value in managing burns $>60 \%$ total body surface area (TBSA), being a life-saving treatment [79]. Although being expensive compared to standard skin autograft, the engraftment rates and survival ratio results make CEAs excellent alternative wound coverage when donor sites are limited in severe burns [80]. Studies reported an average graft take of $72.7 \%$ with a $91 \%$ overall survival rate in treating critically burns using CEA, indicating cultured keratinocytes as an excellent alternative or adjunct to conventional split-thickness skin grafting [81, 82]. The CEAs were reported to enhance the take of a wide meshed autograft in massive burns and allow for grafting wide meshed autograft together with acellular dermal matrix in some cases [83] and were observed to improve skin texture of burn scars after resurfacing the wounds [84]. The use of CEA in treating a full-thickness skin wound in severely burned patients results in favourable quality of scars and was reported to show good potential to save lives by providing epidermal cover [85]. Early excision followed by temporary coverage with autograft, which is allowed to engraft, was found to be associated with a low infection rate and a higher rate of CEA take [86]. CEAs regenerate a stable normal epidermis and are capable of inducing dermal regeneration from wound bed connective tissue [68, 84]. Better outcomes in aesthetic appearances and scar formation were also reported in burn patients grafted with CEAs [87].

In addition, the procedure can be initiated with a small skin biopsy causing minimum donor site morbidity. This would be particularly important for patients with extensive burns as a life-saving device. CEAs deliver living autologous epidermal stem cells for permanent wound closure without eliciting immunological rejection. CEAs could also function as biological wound dressings delivering the much needed biological factors and niche environment for wound healing.

\section{Cultured keratinocyte suspension}

In 1952, Billingham and Reynolds examined the potentials of transplanting sheets of pure epidermal epithelium and non-cultured epidermal cell suspensions for wound healing in guinea pigs [5]. In treating burn patients, the burn wound areas often require early excisions and then immediate skin grafting. While a skin sample could be taken for growing CEAs, a 3-week waiting time for CEA growth would be too long for many patients as it unnecessarily delays the surgical intervention. Consequently, the keratinocytes were cultured only to sub-confluent stage or be grown on carrier material to allow early harvesting and application as cell suspension or sub-confluent sheet $[88,89]$.

Autologous keratinocytes isolated from any available donor site area including sole and scalp [90] could be isolated and cultured for clinical application. The delivery of cultured keratinocytes in suspensions, directly to the wound or in combination with skin grafting, accelerated epidermal wound healing in animal models and burn patients $[90,91]$. The transplantation of cultured keratinocytes were found to facilitate the reformation of organised epidermal structure [69] and to promote permanent epithelialisation in the burn wound $[92,93]$ and accelerated epithelial maturation in an in vivo wound model [94]. Permanent repigmentation of piebaldism was also reported in patients treated by erbium:YAG laser and autologous cultured epidermis [95]. 
To ensure the effectiveness of living keratinocytes for burn wound healing, the cells were delivered in many ways. Co-spray of cultured keratinocytes and autologous fibrin sealant helped retaining the cells in wound and appeared an effective means of keratinocyte delivery for wound healing [96, 97]. Grafting of a fibrin-based culture improved adhesion and development of the epidermis and graft take onto the artificial dermis [98]. Cultured keratinocytes sped up the epithelisation when used in combination with the Meek technique in achieving wound closure in the severely burned paediatric patients [99] and led to permanent burn wound coverage when being grafted with allodermis in burn wound [100, 101].

Sub-confluent autologous keratinocytes were also grown on polymer materials and successfully transferred to achieve would closure [102-105]. The technique significantly reduced the grafting time to within 5-7 days of receipt of biopsy and ensured the cell delivery. High yields of proliferating autologous keratinocytes can be grown on gelatin microbeads and delivered to epithelialise cutaneous wound [106-108]. Less wound contraction was reported when keratinocytes on carrier beads were delivered for wound healing [107].

\section{Non-cultured epidermal cell suspension}

A quick procedure using non-cultured autologous epidermal cells for wound healing was also reported [5, 109]. It involved isolating the epidermal cells from a small skin sample by enzymatic digestion, preparing a basal cell-enriched suspension and redistributing the cells by spraying or dripping to the debrided or granulated wound area to facilitate permanent wound closure or to correct the pigmentation loss. The isolated living cells were then re-distributed immediately to a larger wound surface area at 1:80-100 expansion ratio for fast wound epithelisation [110].

The use of non-cultured epidermal suspension is a fast procedure that involves minimal tissue manipulation and can be completed within a couple of hours in surgical settings. The non-cultured epidermal cells can be used alone or in combination with meshed grafts for wound healing. It was reported to promote wound epithelialisation and reduce the required surgical intervention and total length of stay in treating burns and donor site wounds $[109,111]$. However, wound reepithelialisation and the number of keratinocyte colonies were significantly less in wounds transplanted with noncultured keratinocytes compared to wounds with cultured keratinocytes [91].

Due to the existence of melanocytes in epidermal harvests, the non-cultured epidermal cell suspension helped in correcting the skin hypopigmentation post burns or repigmenting vitiligo [112-115].

\section{Scaffold-guided co-culture and skin regeneration}

Severe burns usually involve detrimental damages to the dermal matrix niche that is essential for structural support, cell attachment, migration, proliferation and differentiation. While CEAs, cultured keratinocytes or epidermal cell suspensions facilitate wound healing and epithelialisation, they showed limitations in treating deep burn wounds that lack dermal foundation. Artificial dermal regenerative templates such as Integra and MatriDerm [4] are commonly used for dermal regeneration in treating deep burns. They are porous bio-scaffolding structures made of biodegradable polymers including proteins and proteoglycans. They provide structural supports and niche matrix for cell attachment, migration and proliferation, and more importantly, they allow the concurrent application of multiple cell types, cell-cell and cellmatrix interactions for engineered skin tissue regeneration and therapeutic purposes. Dermal scaffolds together with cultured keratinocytes and fibroblasts enable in vitro generation of living, durable skin substitutes within several weeks, with reconstructed epidermis and dermis of close to normal histological appearance [116, 117]. Scaffoldguided co-culture of different skin cells synergistically enhance the production of bio-factors and cytokines that benefit wound healing. Increased expression of integrins and decreased apoptosis correlate with increased melanocyte retention in cultured skin substitutes [118]. The autologous living skin substitutes were proved to be clinically effective in severe burn management, resulting in permanent wound closure with improved aesthetic outcomes and minimising donor site casualty [115]. In addition, other cell types including endothelial cells, melanocytes, MSCs could also be seeded to produce engineered skin equivalents with microvascular network, skin appendages and pigmentation, which share more structural and functional similarities to natural skin [119-122]. The in vitro pre-microvascularisation of engineered skin substitute could inosculate with host vasculature to enhance in vivo graft survival. 3D Skin Equivalents were also reconstituted from human iPSCs [54]. Co-culture of KSCs and dermal fibroblast cells with dermal regenerative scaffold enable the development of living skin substitute with structures comparable to natural skin. It indicated that the full-skin substitute has a greater potential to stimulate wound healing than epidermal or dermal substitutes alone.

\section{MSC- and iPSC-based therapies}

MSCs including BM-MSCs and ADSCs have demonstrated great potentials in acute and chronic wound healing and skin repair [123-125]. They promote wound healing through enhanced cell migration, differentiation 
and release of signalling cytokines and bio-factors to regulate the process of angiogenesis [126, 127].

The subcutaneous adipose tissue from debrided skin in burn surgery can be a rich source of ADSCs for many applications such as being grafted as cutaneous wound therapy or for tissue engineering [128]. Autologous ADSC-enhanced healing of cutaneous radiation syndrome was observed in a mini-pig model [129].

BM-MSCs were reported to enhance wound healing quality and facilitate skin regeneration after fullthickness injury, with the grafted cells transdifferentiating into cell types including vascular endothelial cells, sebaceous duct cells and epidermal cells [122].

Allogenic human umbilical cord mesenchymal stem cells (hUCMSCs) and BM-MSCs are being trialled clinically for treating acute or second-degree burns [130, 131] but no results have been reported until now. BMMSCs in hydrogels could be a promising therapeutic strategy for curing chronic wound including diabetic ulcers [124]. Autogenic BM-MSCs transferred with collagen membrane were seen to repair full-thickness cutaneous deficiency in porcine model [132]. ADSCs were reported to modulate development of hypertrophic scarring in a red Duroc porcine model [42] and attenuate scar formation during wound healing [133, 134].

Patient-specific and gene-corrected iPSCs, expressing collagen 7 , were developed with the inherent capacity to treat recessive dystrophic epidermolysis bullosa, a severe and often lethal condition caused by mutations in the COL7A1 gene-encoding type VII collagen [135]. Very recently, the entire human epidermis could be generated using transgenic stem cells for the genetic disease [136].

\section{Considerations and future directions}

The evidence from laboratory, animal and clinical studies demonstrate that cell-based therapy is becoming an important alternative or conjunctive treatment for burn wound management. It is important to point out that cell therapy devices and associated procedures are now highly regulated by global authorities to ensure their bio-safety and efficacy. While animal sourced reagents could cause concerns, unresolved issues also exist in the potential applications using MSCs and iPSCs. It is also important to understand that MSCs from different sources could have different immunomodulation capabilities and varied capacities to proliferate and differentiate to various cells. If allogeneic MSCs are used, their immunogenicity could have impact on their in vivo durability. More studies are needed to define those issues as they could potentially affect the therapeutic outcomes [137]. Also, MSCs were reported to enhance tumour formation and growth in vivo and metastasis [138-143]. The biosafety of retroviral vectors for transcriptional factor delivery in making iPSCs also need to be examined in long-term investigations for any associated cancer risk, epigenetic memory retained from parent cells, genetic instability and potential immunogenicity [56, 144].

Until now, cultured keratinocytes and non-cultured epidermal isolates are the most used devices for treating burns. Cultured epidermis and skin substitutes are only structurally similar but will never be identical to natural skin as evidenced by the differences in their gene expression profiles [145]. They are fragile and more susceptible to mechanical shearing forces and are more sensitive to infections due to an insufficient level of beta-defensins, the antimicrobial peptides [146]. CEAs also displayed poor adherence, poor stability and delay in rete ridge formation and elastin filament development [147] and lacking or delayed basement membrane [117] post grafting. Although the potential and feasibility for the use in the treatment of burns were demonstrated, the data were mainly generated from laboratory analysis, animal studies, case reports and observations of small patient cohorts lacking of proper controls. More reliable and randomly controlled trials in a large scale are still needed to assess the efficacy and to understand the full capacities of each cellular device in burn wound healing, scarring and skin repair.

More research and development should be carried out to address the following technical problems and factors that could affect the outcomes of cell therapy. For example, the time needed for generating autologous CEAs or scaffold-guided living skin substitutes is often too long for managing acute burns. Technical improvement is needed to ensure the timely supply of cultured cellular products for burn wound healing when early debridement was carried out in treating burns. The use of cultured cell suspension as well as non-cultured cells significantly reduced the preparation time for cellular products but came across other issues following their delivery. The cloning efficiency is more of a concern with non-cultured epidermal cells as the freshly isolated cells showed very low efficiency in cloning or replicating themselves [63, 68, 70]. The run-off issue of cell suspension from the wound surface could further decrease the number of cells actually retained in the wound after delivery. In addition, other factors including wound depth, wound bed preparation, and wound infection further complicate the application of cell therapy and lead to variable outcomes. As timing is always critical for surgical intervention in treating burns, the successful use of cell therapy also depends on the well-coordinated collaboration between clinical scientists, surgeons and nursing staff.

\section{Conclusions}

Cell therapy has emerged as an important component of life-saving and wound healing procedures in treating burns. Although progresses have been made to 
demonstrate the potential and feasibility of various stem cells for burn wound healing, there are still scientific and technical issues that should be resolved to facilitate the full potential of the cellular devices. More evidence is needed from research and large, randomly controlled trials to define the clinical efficacy and safety of cell therapy in burns.

\section{Authors' contributions}

Both ZL and PM contribute to the contents and approved the final version of this manuscript.

\section{Ethics approval and consent to participate}

Not applicable

\section{Competing interests}

The authors declare that they have no competing interests.

\section{Author details}

${ }^{1}$ Burns Unit, Concord Hospital, Concord, New South Wales 2139, Australia. ${ }^{2}$ Skin Laboratory, NSW Statewide Burns Service, Concord, New South Wales, Australia. ${ }^{3}$ Discipline of Surgery, University of Sydney Medical School,

Camperdown, New South Wales, Australia.

\section{Received: 21 December 2017 Accepted: 26 April 2018}

Published online: 28 May 2018

\section{Reference}

1. Burns Fact. Aug 2017. http//wwwwho.int/mediacentre/factsheets/fs365/en/

2. Hettiaratchy S, Dziewulski P. Pathophysiology and types of burns. BMJ. 2004 328:1427-9.

3. Stanton RA, Billmire DA. Skin resurfacing for the burned patient. Clin Plast Surg. 2002;29(1):29-51.

4. Halim AS, Khoo TL, Yussof MSJ. Biologic and synthetic skin substitutes: an overview. Indian J Plast Surg. 2010:43(Suppl):S23-8.

5. Billingham RE, Reynolds J. Transplantation studies on sheets of pure epidermal epithelium and on epidermal cell suspensions. Br J Plast Surg. 1952;5:25-36.

6. Rheinwald JG, Green H. Serial cultivation of strains of human epidermal keratinocytes: the formation of keratinizing colonies from single cells. Cell. 1975;6:331-43

7. Green $\mathrm{H}$, Kehinde O, Thomas J. Growth of cultured human epidermal cells into multiple epithelia suitable for grafting. Proc Natl Acad Sci U S A. 1979; 76:5665-8.

8. O'Connor NE, Mulliken JB, Banks-Schlegel S, Kehinde O, Green H. Grafting of burns with cultured epithelium prepared from autologous epidermal cells. Lancet. 1981;317:75-8.

9. Fuchs E. Skin stem cells: rising to the surface. J Cell Biol. 2008;180(2):273-84.

10. Blanpain C, Fuchs E. Epidermal stem cells of the skin. Annu Rev Cell Dev Biol. 2006;22:339-73.

11. Fuchs E. Finding one's niche in the skin. Cell Stem Cell. 2009:4(6):499-502.

12. Miller SJ, Lavker RM, Sun TT. Keratinocyte stem cells of cornea skin and hai follicles. In: Potten CS, editor. Stem Cells. San Diego: Academic Press Inc.; 1997. p. 331-62

13. Barrandon $Y$, Green $H$. Three clonal types of keratinocyte with different capacities for multiplication. Proc Natl Acad Sci U S A. 1987;84:2302-6.

14. Potten CS, Booth C. Keratinocyte stem cells: a commentary. J Invest Dermatol. 2002;119:888-99.

15. Dowling J, Yu QC, Fuchs E. Beta4 integrin is required for hemidesmosome formation, cell adhesion and cell survival. J Cell Biol. 1996;134:559-72.

16. Mcheik JN, Barrault C, Pedretti N, Garnier J, Juchaux F, Levard G, et al. Foreskin-isolated keratinocytes provide successful extemporaneous autologous paediatric skin grafts. J Tissue Eng Regen Med. 2016;10(3): 252-60

17. Gröne A. Keratinocytes and cytokines. Vet Immunol Immunopathol. 2002; $88(1-2): 1-12$.

18. Nair RP, Krishnan LK. Identification of p63+ keratinocyte progenitor cells in circulation and their matrix-directed differentiation to epithelial cells. Stem Cell Res Ther. 2013;4(2):38. https://doi.org/10.1186/scrt186.
19. Kubo K, Kuroyanagi Y. A study of cytokines released from fibroblasts in cultured dermal substitute. Artif Organs. 2005:29(10):845-9.

20. Sorrell JM, Baber MA, Caplan Al. Site-matched papillary and reticular human dermal fibroblasts differ in their release of specific growth factors/cytokines and in their interaction with keratinocytes. J Cell Physiol. 2004;200(1):134-45.

21. Spiekstra SW, Breetveld M, Rustemeyer T, Scheper RJ, Gibbs S. Woundhealing factors secreted by epidermal keratinocytes and dermal fibroblasts in skin substitutes. Wound Repair Regen. 2007;15(5):708-17.

22. Kubo K, Kuroyanagi Y. The possibility of long-term cryopreservation of cultured dermal substitute. Artif Organs. 2005;29(10):800-5.

23. Goretsky MJ, Harriger MD, Supp AP, Greenhalgh DG, Boyce ST. Expression of interleukin-1alpha, interleukin-6, and basic fibroblast growth factor by cultured skin substitutes before and after grafting to full-thickness wound in athymic mice. J Trauma. 1996;40(6):894-9. discussion 899-900

24. Maas-Szabowski N, Shimotoyodome A, Fusenig NE. Keratinocyte growth regulation in fibroblast cocultures via a double paracrine mechanism. J Cell Sci. 1999:112(Pt 12):1843-53.

25. Toma JG, Akhavan M, Fernandes KJ, Barnabé-Heider F, Sadikot A, Kaplan DR Miller FD. Isolation of multipotent adult stem cells from the dermis of mammalian skin. Nat Cell Biol. 2001;3(9):778-84.

26. Fernandes KJ, McKenzie IA, Mill P, Smith KM, Akhavan M, Barnabé-Heider F, et al. A dermal niche for multipotent adult skin-derived precursor cells. Nat Cell Biol. 2004;6(11):1082-93.

27. Takahashi K, Yamanaka S. Induction of pluripotent stem cells from mouse embryonic and adult fibroblast cultures by defined factors. Cell. 2006:126(4): $663-76$

28. Takahashi K, Tanabe K, Ohnuki M, Narita M, Ichisaka T, Tomoda K, Yamanaka S. Induction of pluripotent stem cells from adult human fibroblasts by defined factors. Cell. 2007;131(5):861-72

29. Dominici M, Le Blanc K, Mueller I, Slaper-Cortenbach I, Marini F, Krause D, et al. Minimal criteria for defining multipotent mesenchymal stromal cells. The International Society for Cellular Therapy position statement. Cytotherapy. 2006:8:315-7.

30. Ding D, Shyu W, Lin S. Mesenchymal stem cells. Cell Transpl. 2011:20:5-14.

31. Liao $Y$, Itoh M, Yang A, Zhu H, Roberts S, Highet AM, et al. Human cord blood-derived unrestricted somatic stem cells promote wound healing and have therapeutic potential for patients with recessive dystrophic epidermolysisbullosa. Cell Transplant. 2014;23:303-17.

32. Duscher D, Barrera J, Wong WW, Maan ZN, Whittam AJ, Januszyk M, et al. Stem cells in wound healing: the future of regenerative medicine? Gerontology. 2016;62:216-25

33. Ren G, Zhang L, Zhao X, Xu G, Zhang Y, Roberts Al, et al. Mesenchymal stem cell-mediated immunosuppression occurs via concerted action of chemokines and nitric oxide. Cell Stem Cell. 2008;2:141-50.

34. Le Blanc K, Frassoni F, Ball L, Locatelli F, Roelofs $H$, Lewis I, et al. Mesenchymal stem cells for treatment of steroid-resistant, severe, acute graft-versus-host disease: a phase II study. Lancet. 2008;371(9624):1579-86.

35. Pittenger MF, Mackay AM, Beck SC, Jaiswal RK, Douglas R, Mosca JD, et al. Multilineage potential of adult human mesenchymal stem cells. Science. 1999;284(5411):143-7

36. Kwon HM, Hur SM, Park KY, Kim CK, Kim YM, Kim HS, et al. Multiple paracrine factors secreted by mesenchymal stem cells contribute to angiogenesis. Vasc Pharmacol. 2014;63(1):19-28

37. Sasaki M, Abe R, Fujita Y, Ando S, Inokuma D, Shimizu H. Mesenchymal stem cells are recruited into wounded skin and contribute to wound repair by transdifferentiation into multiple skin cell type. J Immunol. 2008;180(4): 2581-7.

38. Caplan Al, Dennis JE. Mesenchymal stem cells as trophic mediators. J Cell Biochem. 2006;98:1076-84

39. Falanga V, Iwamoto S, Chartier M, Yufit T, Butmarc J, Kouttab N, et al. Autologous bone marrow-derived cultured mesenchymal stem cells delivered in a fibrin spray accelerate healing in murine and human cutaneous wounds. Tissue Eng. 2007;13:1299-312.

40. Badiavas EV, Falanga V. Treatment of chronic wounds with bone marrowderived cells. Arch Dermatol. 2003;139:510-6.

41. Lee DE, Ayoub N, Agrawal DK. Mesenchymal stem cells and cutaneous wound healing: novel methods to increase cell delivery and therapeutic efficacy. Stem Cell Res Ther. 2016;7:37. https://doi.org/10.1186/s13287-016 0303-6

42. Foubert P, Zafra D, Liu M, Rajoria R, Gutierrez D, Tenenhaus M, et al. Autologous adipose-derived regenerative cell therapy modulates 
development of hypertrophic scarring in a red Duroc porcine model. Stem Cell Res Ther. 2017;8(1):261. https://doi.org/10.1186/s13287-017-0704-1.

43. Won $\mathrm{CH}$, Yoo HG, Kwon OS, Sung MY, Kang YJ, Chung JH, et al. Hair growth promoting effects of adipose tissue-derived stem cells. J Dermatol Sci. 2010; 57:134-7.

44. Park BS, Kim WS, Choi JS, Kim HK, Won JH, Ohkubo F, et al. Hair growth stimulated by conditioned medium of adipose-derived stem cells is enhanced by hypoxia: evidence of increased growth factor secretion. Biomed Res. 2010;31(1):27-34.

45. Sheng Z, Fu X, Cai S, Lei Y, Sun T, Bai $X$, et al. Regeneration of functional sweat gland-like structures by transplanted differentiated bone marrow mesenchymal stem cells. Wound Rep Reg. 2009;17(3):427-35.

46. Jackson L, Jones DR, Scotting P, Sottile V. Adult mesenchymal stem cells: differentiation potential and therapeutic applications. J Postgrad Med. 2007;53:121-7.

47. Ji L, Allen-Hoffmann BL, de Pablo JJ, Palecek SP. Generation and differentiation of human embryonic stem cell-derived keratinocyte precursors. Tissue Eng. 2006;12(4):665-79.

48. Green H, Easley K, luchi S. Marker succession during the development of keratinocytes from cultured human embryonic stem cells. Proc Natl Acad Sci U S A. 2003;100(26):15625-30.

49. Bilousova G, Chen J, Roop DR. Differentiation of mouse induced pluripotent stem cells into a multipotent keratinocyte lineage. J Invest Dermatol. 2011; 131(4):857-64.

50. Kidwai FK, Liu H, Toh WS, Fu X, Jokhun DS, Movahednia MM, et al. Differentiation of human embryonic stem cells into clinically amenable keratinocytes in an autogenic environment. J Investig Dermatol. 2013;133(3): 618-28.

51. Guenou H, Nissan X, Larcher F, Feteira J, Lemaitre G, Saidani M, et al. Human embryonic stem-cell derivatives for full reconstruction of the pluristratified epidermis: a preclinical study. Lancet. 2009;374:1745-53.

52. Luchi S, Dabelsteen S, Easley K, Rheinwald JG, Green H. Immortalized keratinocyte lines derived from human embryonic stem cells. Proc Natl Acad Sci U S A. 2006;103(6):1792-7

53. Shamis Y, Hewitt KJ, Carlson MW, Margvelashvilli M, Dong S, Kuo CK, et al, Fibroblasts derived from human embryonic stem cells direct development and repair of 3D human skin equivalents. Stem Cell Res Ther. 2011;2(1):10. https://doi.org/10.1186/scrt51

54. Itoh M, Umegaki-Arao N, Guo Z, Liu L, Higgins CA, et al. Generation of 3D skin equivalents fully reconstituted from human induced pluripotent stem cells(iPSCs). PLoS One. 2013;8(10):e77673. https://doi.org/10.1371/journal. pone.0077673.

55. Greene WA, Burke TA, Por ED, Kaini RR, Wang HC. Secretion profile of induced pluripotent stem cell-derived retinal pigment epithelium during wound healing. Invest Ophthalmol Vis Sci. 2016;57(10):4428-41.

56. Okano H, Nakamura M, Yoshida K, Okada Y, Tsuji O, Nori S, et al. Steps toward safe cell therapy using induced pluripotent stem cells. Circ Res. 2013:112:523-33

57. Revilla A, González C, Iriondo A, Fernández B, Prieto C, Marín C, et al. Current advances in the generation of human iPS cells: implications in cellbased regenerative medicine. J Tissue Eng Regen Med. 2016;10:893-907.

58. Okita K, Yamakawa T, Matsumura Y, Sato Y, Amano N, Watanabe A, et al. An efficient nonviral method to generate integration-free human-induced pluripotent stem cells from cord blood and peripheral blood cells. Stem Cells. 2013;31:458-66.

59. Kime C, Rand TA, Ivey KN, Srivastava D, Yamanaka S, Tomoda K. Practical integration-free episomal methods for generating human induced pluripotent stem cells. Curr Protoc Hum Genet. 2015;87:21.2.1-21.

60. Gao ZR, Hao ZQ, Nie LJ, Liu GF. Coverage of full skin thickness burns with allograft inoculated with autogenous epithelial cells. Burns Incl Therm Inj. 1986;12:220-4

61. Elberg JJ, Siemssen SJ, Nielsen EH, Ronne M. Grafting of human autogenous keratinocytes cultured in vitro. In Vivo. 1990;4:367-9.

62. Brychta P, Michálek V, Adler J, Ríhová H, Suchánek I. Use of cultured epidermal autotransplantation in a severely burned patient. Rozhl Chir 1993;72(5):216-8

63. Spilker G, Reifenrath MW, Kaiser HW. Skin cultivation in treatment of severely burned patients. Langenbecks Arch Chir Suppl Kongressbd. 1996; 113:1149-55.

64. Williamson JS, Snelling CF, Clugston P, Macdonald IB, Germann E. Cultured epithelial autograft: five years of clinical experience with twenty-eight patients. J Trauma. 1995;39(2):309-19.
65. Paddle-Ledinek JE, Cruickshank DG, Masterton JP. Skin replacement by cultured keratinocyte grafts: an Australian experience. Burns. 1997;23(3):20411.

66. Ativeh BS, Costagliola M. Cultured epithelial autograft (CEA) in burn treatment: three decades later. Burns. 2007;33(4):405-13.

67. Wood FM, Kolybaba ML, Allen P. The use of cultured epithelial autograft in the treatment of major burn wounds: eleven years of clinical experience. Burns. 2006;32(5):538-44

68. Wood FM, Giles N, Stevenson A, Rea S, Fear M. Characterisation of the cell suspension harvested from the dermal epidermal junction using a ReCell ${ }^{\oplus}$ kit. Burns. 2012;38(1):44-51.

69. Fei $X$, Seah CS, Lee ST. Human keratinocyte cell culture for the burns patients - a preliminary report. Ann Acad Med Singap. 1991;20(4):493-7.

70. Ronfard V, Rives JM, Neveux Y, Carsin H, Barrandon Y. Long-term regeneration of human epidermis on third degree burns transplanted with autologous cultured epithelium grown on a fibrin matrix. Transplantation. 2000;70(11):1588-98.

71. Compton CC, Nadire KB, Regauer S, Simon M, Warland G, O'Connor NE, et al. Cultured human sole-derived keratinocyte grafts re-express site-specific differentiation after transplantation. Differentiation. 1998;64(1):45-53.

72. Worst PKM, Mackenzie IC, Fusenig NE. Reformation of organized epidermal structure by transplantation of suspensions and cultures of epidermal and dermal cells. Cell Tissue Res. 1982;225(1):65-77.

73. van den Bogaerdt AJ, Ulrich MM, van Galen MJ, Reijnen L, Verkerk M, Pieper J, et al. Upside-down transfer of porcine keratinocytes from a porous, synthetic dressing to experimental full-thickness wounds. Wound Repair Regen. 2004;12(2):225-34.

74. Loss M, Wedler V, Künzi W, Meuli-Simmen C, Meyer VE. Artificial skin, splitthickness autograft and cultured autologous keratinocytes combined to treat a severe burn injury of 93\% of TBSA. Burns. 2000;26(7):644-52.

75. Haith LR Jr, Patton ML, Goldman WT. Cultured epidermal autograft and the treatment of the massive burn injury. J Burn Care Rehabil. 1992;13(1):142-6.

76. Krupp S, Benathan M, Meuli M, Déglise B, Holzer E, Wiesner L, et al. Current concepts in pediatric burn care: management of burn wounds with cultured epidermal autografts. Eur J Pediatr Surg. 1992;2(4):210-5.

77. Still JM Jr, Orlet HK, Law EJ. Use of cultured epidermal autografts in the treatment of large burns. Burns. 1994;20(6):539-41.

78. López Gutiérrez JC, Ros Z, Vallejo D, Perdiquero M, Soto C, Tovar J. Cultured epidermal autograft in the management of critical pediatric burn patients. Eur J Pediatr Surg. 1995:5(3):174-6.

79. Carsin H, Ainaud P, Le Bever H, Rives J, Lakhel A, Stephanazzi J, et al. Cultured epithelial autografts in extensive burn coverage of severely traumatized patients: a five year single-center experience with 30 patients. Burns. 2000;26(4):379-87.

80. Chalumeau M, Saulnier JP, Ainaud P, Lebever H, Stephanazzi J, Lecoadou A, et al. Initial general management and surgery of six extensively burned children treated with cultured epidermal autografts. J Pediatr Surg. 1999; 34(4):602-5

81. Sood R, Balledux J, Koumanis DJ, Mir HS, Chaudhari S, Roggy D, et al. Coverage of large pediatric wounds with cultured epithelial autografts in congenital nevi and burns: results and technique. J Burn Care Res. 2009: 30(4):576-86.

82. Sood R, Roggy D, Zieger M, Balledux J, Chaudhari S, Koumanis DJ, et al. Cultured epithelial autografts for coverage of large burn wounds in eightyeight patients: the Indiana University experience. J Burn Care Res. 2010; 31(4):559-68.

83. Yim H, Yang HT, Cho YS, Seo $\mathrm{CH}$, Lee BC, Ko JH, et al. Clinical study of cultured epithelial autografts in liquid suspension in severe burn patients. Burns. 2011;37(6):1067-71.

84. Soejima K, Nozaki M, Kobayashi M, Negishi N. Studies of surface microarchitecture using a hand-held video microscope in cases of cultured epithelial autografts. Ann Plast Surg. 1998:41(3):270-4.

85. Lee H. Outcomes of sprayed cultured epithelial autografts for full-thickness wounds: a single-centre experience. Burns. 2012;38(6):931-6.

86. Odessey R. Addendum: multicenter experience with cultured epidermal autograft for treatment of burns. J Burn Care Rehabil. 1992;13(1):174-80

87. Compton CC. Current concepts in pediatric burn care: the biology of cultured epithelial autografts: an eight-year study in pediatric burn patients. Eur J Pediatr Surg. 1992;2(4):216-22.

88. Hernon CA, Dawson RA, Freedlander E, Short R, Haddow DB, Brotherston M, et al. Clinical experience using cultured epithelial autografts leads to an 
alternative methodology for transferring skin cells from the laboratory to the patient. Regen Med. 2006;1 (6):809-21.

89. Hartmann B, Ekkernkamp A, Johnen C, Gerlach JC, Belfekroun C, Küntscher MV. Sprayed cultured epithelial autografts for deep dermal burns of the face and neck. Ann Plast Surg. 2007;58(1):70-3.

90. Schlabe J, Johnen C, Schwartlander R, Moser V, Hartmann B, Gerlach JC, et al. Isolation and culture of different epidermal and dermal cell types from human scalp suitable for the development of a therapeutical cell spray. Burns. 2008;34(3):376-84

91. Svensjö T, Yao F, Pomahac B, Eriksson E. Autologous keratinocyte suspensions accelerate epidermal wound healing in pigs. J Surg Res. 2001; 99(2):211-21.

92. Pellegrini G, Ranno R, Stracuzzi G, Bondanza S, Guerra L, Zambruno G, et al. The control of epidermal stem cells (holoclones) in the treatment of massive full-thickness burns with autologous keratinocytes cultured on fibrin. Transplantation. 1999;68(6):868-79.

93. Oshima $\mathrm{H}$, Inoue $\mathrm{H}$, Matsuzaki K, Tanabe M, Kumagai N. Permanent restoration of human skin treated with cultured epithelium grafting-wound healing by stem cell based tissue engineering. Hum Cell. 2002;15(3):118-28.

94. Magnusson M, Papini RP, Rea SM, Reed CC, Wood FM. Cultured autologous keratinocytes in suspension accelerates epithelial maturation in an in vivo wound model as measured by surface electrical capacitance. Plast Reconstr Surg. 2007;119(2):495-9.

95. Guerra L, Primavera G, Raskovic D, Pellegrini G, Golisano O, Bondanza S, et al. Permanent repigmentation of piebaldism by erbium:YAG laser and autologous cultured epidermis. Br J Dermatol. 2004;150(4):715-21.

96. Grant I, Warwick K, Marshall J, Green C, Martin R. The co-application of sprayed cultured autologous keratinocytes and autologous fibrin sealant in a porcine wound model. Br J Plast Surg. 2002;55(3):219-27.

97. Kopp J, Jeschke MG, Bach AD, Kneser U, Horch RE. Applied tissue engineering in the closure of severe burns and chronic wounds using cultured human autologous keratinocytes in a natural fibrin matrix. Cell Tissue Bank. 2004;5(2):89-96.

98. Mis B, Rolland E, Ronfard V. Combined use of a collagen-based dermal substitute and a fibrin-based cultured epithelium: a step toward a total skin replacement for acute wounds. Burns. 2004;30(7):713-9.

99. Menon S, Li Z, Harvey JG, Holland AJ. The use of the meek technique in conjunction with cultured epithelial autograft in the management of major paediatric burns. Burns. 2013;39(4):674-9.

100. Hickerson WL, Compton C, Fletchall S, Smith LR. Cultured epidermal autografts and allodermis combination for permanent burn wound coverage. Burns. 1994;20(Suppl 1):S52-5. discussion S55-56

101. Sheridan RL, Morgan JR, Cusick JL, Petras LM, Lydon MM, Tompkins RG. Initial experience with a composite autologous skin substitute. Burns. 2001; 27(5):421-4.

102. Tay AG, Phan TT, See P, Teik LS, Song C. Cultured subconfluent keratinocytes on wound polymer dressings in the treatment of burns and chronic wounds. Wounds. 2000;12(5):123-9.

103. Chua AW, Ma DR, Song IC, Phan TT, Lee ST, Song C. In vitro evaluation of fibrin mat and Tegaderm wound dressing for the delivery of keratinocytes-implications of their use to treat burns. Burns. 2008;34(2): 175-80.

104. Burt AM and Clarke J.A. Transfer of autologous keratinocytes grown on a polymer reduces time taken from biopsy to graft. Annals of Burns and Fire Disasters - Vol. X - N. 4 - December 1997.

105. Myers SR, Partha VN, Soranzo C, Price RD, Navsaria HA. Hyalomatrix: a temporary epidermal barrier, hyaluronan delivery, and neodermis induction system for keratinocyte stem cell therapy. Tissue Eng. 2007;13(11):2733-41.

106. Liu JY, Hafner J, Dragieva G, Burg G. A novel bioreactor microcarrier cell culture system for high yields of proliferating autologous human keratinocytes. Cell Transplant. 2006;15(5):435-43.

107. Eldardiri M, Martin Y, Roxburgh J, Lawrence-Watt DJ, Sharpe JR. Wound contraction is significantly reduced by the use of microcarriers to deliver keratinocytes and fibroblasts in an in vivo pig model of wound repair and regeneration. Tissue Eng Part A. 2012;18(5-6):587-97.

108. Gustafson CJ, Birgisson A, Junker J, Huss F, Salemark L, Johnson H, et al. Employing human keratinocytes cultured on macroporous gelatin spheres to treat full thickness-wounds: an in vivo study on athymic rats. Burns. 2007;33(6):726-35.

109. Wood FM, Stoner ML, Fowler BV, Fear MW. The use of a non-cultured autologous cell suspension and Integra dermal regeneration template to repair full-thickness skin wounds in a porcine model: a one-step process. Burns. 2007;33(6):693-700.

110. Esteban-Vives R, Young MT, Zhu T, Beiriger J, Pekor C, Ziembicki J, et al. Calculations for reproducible autologous skin cell-spray grafting. Burns. 2016;42(8):1756-65.

111. Gerlach JC, Johnen C, Ottoman C, Bräutigam K, Plettig J, Belfekroun C, et al. Method for autologous single skin cell isolation for regenerative cell spray transplantation with non-cultured cells. Int J Artif Organs. 2011;34(3):271-9.

112. Paul M. Autologous non-cultured basal cell-enriched epidermal cell suspension transplantation in vitiligo: Indian experience. J Cutan Aesthet Surg. 2011;4(1):23-8.

113. Stoner ML, Wood FM. The treatment of hypopigmented lesions with cultured epithelial autograft. J Burn Care Rehabil. 2000;21(1 Pt 1):50-4.

114. van Geel N, Ongenae K, De Mil M, Haeghen W, Vervaet C, Naeyaert JM. Double-blind placebo-controlled study of autologous transplanted epidermal cell suspensions for repigmenting vitiligo. Arch Dermatol. 2004; 140(10):1203-8.

115. Hivelin M, Maclver C, Heusse JL, Atlan M, Lantieri L. Improving the colour match of free tissue transfers to the face with non-cultured autologous cellular spray - a case report on a chin reconstruction. J Plast Reconstr Aesthet Surg. 2012;65(8):1103-6.

116. Boyce ST, Kagan RJ, Yakuboff KP, Meyer NA, Rieman MT, Greenhalgh DG, et al. Cultured skin substitutes reduce donor skin harvesting for closure of excised, full-thickness burns. Ann Surg. 2002;235(2):269-79.

117. Matsumura H, Gondo M, Imai R, Shibata D, Watanabe K. Chronological histological findings of cultured epidermal autograft over bilayer artificial dermis. Burns. 2013;39(4):705-13.

118. Swope VB, Supp AP, Schwemberger S, Babcock G, Boyce S. Increased expression of integrins and decreased apoptosis correlate with increased melanocyte retention in cultured skin substitutes. Pigment Cell Res. 2006; 19(5):424-33.

119. Supp DM, Wilson-Landy K, Boyce ST. Human dermal microvascular endothelial cells form vascular analogs in cultured skin substitutes after grafting to athymic mice. FASEB J. 2002;16(8):797-804.

120. Tremblay PL, Hudon V, Berthod F, Germain L, Auger FA. Inosculation of tissue-engineered capillaries with the host's vasculature in constructed skin transplanted on mice. Am J Transplant. 2005;5(5):1002-10.

121. Gibot L, Galbraith T, Huot J, Auger FA. A preexisting microvascular network benefits in vivo revascularization of a microvascularized tissue-engineered skin substitute. Tissue Eng Part A. 2010;16(10):3199-206.

122. Fu X, Fang L, Li X, Cheng B, Sheng Z. Enhanced wound-healing quality with bone marrow mesenchymal stem cells autografting after skin injury. Wound Repair Regen. 2006;14(3):325-35.

123. Jeong JH. Adipose stem cells and skin repair. Curr Stem Cell Res Ther. 2010; 5(2):137-40.

124. Chen SX, Shi JB, Zhang M, Chen YH, Wang X, Zhang L, et al. Mesenchymal stem cell-laden anti-inflammatory hydrogel enhances diabetic wound healing. Sci Rep. 2005;5:Article number: 18104. https://doi.org/10.1038/ srep18104.

125. Caplan Al, Correa D. The MSC: an injury drugstore. Cell Stem Cell. 2011;9(1): $11-5$.

126. Wu Y, Chen L, Scott PG, Tredget EE. Mesenchymal stem cells enhance wound healing through differentiation and angiogenesis. Stem Cells. 2007; 25:2648-59.

127. Lee EY, Xia Y, Kim WS, Kim MH, Kim TH, Kim KJ, et al. Hypoxia-enhanced wound healing function of adipose-derived stem cells: increase in stem cell proliferation and up-regulation of VEGF and bFGF. Wound Repair Regen. 2009;17(4):540-7.

128. Natesan S, Wrice NL, Baer DG, Christy RJ. Debrided skin as a source of autologous stem cells for wound repair. Stem Cells. 2011;29(8):1219-30.

129. Forcheron F, Agay D, Scherthan H, Riccobono D, Herodin F, Meineke V, et al. Autologous adipocyte derived stem cells favour healing in a minipig model of cutaneous radiation syndrome. PLoS One. 2012;7(2):e31694.

130. Allogenic stem cell therapy in patients with acute burn. Sponsor: Shenzhen Beike Bio-Technology Co., Ltd. https://clinicaltrials.gov/ct2/show/ NCT01443689

131. Stem cell therapy to improve burn wound healing. Sponsor: Badiavas $E_{\text {, }}$ University of Miami. https://clinicaltrials.gov/ct2/show/NCT02104713

132. He L, Liu D, Bai C, Yan Y, Guan L, Pei X. Repair of swine full-thickness cutaneous deficiency by autogenic BMSCs compounded with collagen membrane. Zhongguo Xiu Fu Chong Jian Wai Ke Za Zhi. 2009;23(3):348-52. 
133. Jackson WM, Nesti LJ, Tuan RS. Mesenchymal stem cell therapy for attenuation of scar formation during wound healing. Stem Cell Res Ther. 2012;3(3):20. https://doi.org/10.1186/scrt111.

134. Spiekman M, van Dongen JA, Willemsen JC, Hoppe DL, van der Lei B, Harmsen MC. The power of fat and its adipose-derived stromal cells: emerging concepts for fibrotic scar treatment. J Tissue Eng Regen Med. 2017;11(11):3220-35.

135. Tolar J, Xia L, Riddle MJ, Lees CJ, Eide CR, McElmurry RT, et al. Induced pluripotent stem cells from individuals with recessive dystrophic epidermolysis bullosa. J Invest Dermatol. 2011;131(4):848-56.

136. Hirsch T, Rothoeft T, Teig N, Bauer JW, Pellegrini G, De Rosa L, et al. Regeneration of the entire human epidermis using transgenic stem cells. Nature. 2017;551(7680):327-32.

137. Cheng HY, Ghetu N, Wallace CG, Wei FC, Liao SK. The impact of mesenchymal stem cell source on proliferation, differentiation, immunomodulation and therapeutic efficacy. J Stem Cell Res Ther. 2014;4: 237. https://doi.org/10.4172/2157-7633.1000237.

138. Tian LL, Yue W, Zhu F, Li S, Li W. Human mesenchymal stem cells play a dual role on tumor cell growth in vitro and in vivo. J Cell Physiol. 2011; 226(7):1860-7

139. Karnoub AE, Dash AB, Vo AP, Sullivan A, Brooks MW, Bell GW, et al. Mesenchymal stem cells within tumour stroma promote breast cancer metastasis. Nature. 2007;449(7162):557-63.

140. Shinagawa K, Kitadai Y, Tanaka M, Sumida T, Kodama M, Higashi Y, et al. Mesenchymal stem cells enhance growth and metastasis of colon cancer. Int J Cancer. 2010;127(10):2323-33.

141. Liu C, Chen Z, Chen Z, Zhang T, Lu Y. Multiple tumor types may originate from bone marrow derived cells. Neoplasia. 2006;8(9):716-24.

142. Tolar J, Nauta AJ, Osborn MJ, Panoskaltsis MA, McElmurry RT, Bell S, et al. Sarcoma derived from cultured mesenchymal stem cells. Stem Cells. 2007: 25(2):371-9.

143. Wong RSY. Mesenchymal stem cells: angels or demons? J Biomed Biotechnol. Volume (2011), Article ID 459510, 8 pages doi:https://doi.org/10. 1155/2011/459510

144. Zhang G, Shang B, Yang P, Cao Z, Pan Y, Zhou Q. Induced pluripotent stem cell consensus genes: implication for the risk of tumorigenesis and cancers in induced pluripotent stem cell therapy. Stem Cells Dev. 2012;21(6):955-64.

145. Bernard FX, Pedretti N, Rosdy M, Deguercy A. Comparison of gene expression profiles in human keratinocyte mono-layer cultures, reconstituted epidermis and normal human skin; transcriptional effects of retinoid treatments in reconstituted human epidermis. Exp Dermatol. 2002; 11(1):59-74.

146. Supp DM, Karpinski AC, Boyce ST. Expression of human beta-defensins HBD1, HBD-2, and HBD-3 in cultured keratinocytes and skin substitutes. Burns. 2004;30(7):643-8.

147. Putland M, Snelling CF, Macdonald I, Tron VA. Histologic comparison of cultured epithelial autograft and meshed expanded split-thickness skin graft. J Burn Care Rehabil. 1995;16(6):627-40.

\section{Ready to submit your research? Choose BMC and benefit from:}

- fast, convenient online submission

- thorough peer review by experienced researchers in your field

- rapid publication on acceptance

- support for research data, including large and complex data types

- gold Open Access which fosters wider collaboration and increased citations

- maximum visibility for your research: over $100 \mathrm{M}$ website views per year

At BMC, research is always in progress.

Learn more biomedcentral.com/submissions 